\title{
How Advances of ICT will Impact on Service Systems and on the Delivering of Product-Related Services
}

\author{
Mario Rapaccini and Isabella Porcelli \\ IBIS LAB, Dept. of Industrial Engineering, University of Florence, Florence, Italy \\ \{mario.rapaccini, isabella.porcelli\}@unifi.it
}

\begin{abstract}
Using a multiple case study approach, this paper studies how the boundaries of service systems that provide product-related services are shifting towards self-service and/or super-service configurations, as a consequence of the introduction of modern ICT.
\end{abstract}

Keywords: Service Systems, Augmented Reality, telemetry, product-related services, self-service, super-service.

\section{Introduction}

Anticipating the age of Internet of Things [1] and smart services [2] leading manufacturers such as Rolls-Royce, IBM and GE [3] recently adopted technologies such as telemetry, condition monitoring and other information and communication technologies (ICTs) that entail to the wider paradigm of e-maintenance [4], to catch real-time data from their installed base of products [5,6]. Captured data can be leveraged to provide customers with more effective life-long support and other product-related services (PRS), such as remote control, optimization, routine maintenance, updates/upgrades, and achieve more competitive advantages [7]. However, the widespread adoption of these technologies is expected to radically change the ways PRS are delivered, favoring super-service (i.e. providers perform autonomously - in isolation from the customer - tasks previously done by/with the customer) rather than self-service (i.e. customers perform on her/his own tasks previously done by/with the provider) [8]. Nonetheless the relevance of this subject [9], there is still paucity of scientific research addressing how the boundaries of service systems will be affected by technological innovation in the next years. This paper aims to fill this gap in the context of industrial goods/equipment. The paper is organized as follows: Section 2 provides a brief literature review on the topic of the study. Section 3 outlines the research methodology, while section 4 synthetized the empirical findings. Implications as well as limitations of the paper are discussed in the last section.

\section{Service Systems}

In service systems [10] resources as different as people, information, money and technologies are mutually shared by different entities (i.e. customers, providers) that 
create (or co-create) value by accessing to these resources [11]. For instance, in the case of a field-repair, at least two entities interact: on one side, the customer (i.e. product owner/user) opens the door of her/his house/facility and lets the technician access to the broken product; on the other side, the technician provides know-how, efforts, tools and/or materials to fix the product. To determine the value created in the service system, both entities compare the achieved benefits to the sustained costs. The more benefits exceed costs, the more value is perceived in the service system. If value is perceived to be higher than expected, entities are satisfied. Since value is created in the service system as entities share resources and interact to each other, benefits and costs of both sides are strictly intertwined. In the provision of industrial services, costs are mostly related to the consumption of specific resources (e.g. materials, energy, labor time, etc.), but can occur also as a consequence of (mental/physical) efforts sustained by entities during the service provision [12]. For instance: driving/walking to the product site (physical effort), being embarrassed for not being able to provide the requested information to customer support (psychical discomfort); being disturbed by noise/smell/dirt/unpleasant service environments (sensorial discomforts).

On the other side, benefits from the provision of PRS to industrial equipment are manifold [13] and include [14]: a) ensure minimum disruption when the equipment fails; b) ensure maximum availability of the equipment; c) ensure the capabilities requested to achieve the best/expected outcomes by the use of the equipment. Irrespective of the classification/terminology used by each provider to promote and sell its offering, it emerges that a first type of PRS, namely recovery services, is focused on assuring product recovery with acceptable performances; a second group, namely availability services, is aimed to assure product availability, keeping low disruptions to the customer's processes; lastly, a third category, namely outcome services, are purposed to increase (empower) the capabilities (skills) of the product user so that she/he's not prevented from extracting/realizing the value potentially embedded in artefact. As a result, the inputs supplied by customers and providers into the service systems greatly differ across these classes (see Table 1).

To model in detail each step of value creation or co-creation, we adopted the Process-Chain Network (PCN) visual framework [15]. In PCN, service delivery processes pertain to the regions of direct (i.e. person to person) and surrogate (i.e. person to things) interactions. In the first people interact synchronously and directly (vis-à-vis) or by means of technology mediation (e.g. phone, live chat). In the second, instead, each entity creates value acting on inanimate resources, such as goods, information, etc., as these are provided by other entities. Surrogate interactions from both sides of a service system show that entities can create value in isolation, though using resources supplied by others. As already said, self-services depict situations in which customers are enabled to create value on their own. Conversely, super-service is the case in which providers are allowed to create value on behalf of their customers, acting on their inanimate resources. As technological advances enable new ways of providing PRS, the boundaries between direct and indirect/surrogate interactions, i.e. self- and super-services, may shift. In PCN, technologies that favor super-services and self-service are called, respectively, relieving- and enabling-technologies [15]. 
Table 1. Classification of PRS (source: adapted from [14])

\begin{tabular}{|c|c|c|c|}
\hline PRS types & Product recovery & Product availability & Product outcome \\
\hline Examples & $\begin{array}{l}\text { Installation, preventive } \\
\text { and corrective main- } \\
\text { tenance, provision of } \\
\text { spares and consu- } \\
\text { mables, updates and } \\
\text { upgrades }\end{array}$ & $\begin{array}{l}\text { Inspection, control \& } \\
\text { troubleshooting, evalua- } \\
\text { tion of residual lives, } \\
\text { definition of mainten- } \\
\text { ance programs }\end{array}$ & $\begin{array}{l}\text { Hot line and help } \\
\text { desk, training, con- } \\
\text { sultancy, technical } \\
\text { documentation }\end{array}$ \\
\hline $\begin{array}{l}\text { Resources } \\
\text { supplied by } \\
\text { customers }\end{array}$ & $\begin{array}{l}\text { Products (broken, } \\
\text { deteriorated, etc.) }\end{array}$ & $\begin{array}{l}\text { Mostly information } \\
\text { about product/process } \\
\text { status, functioning pa- } \\
\text { rameters, alerts, etc. }\end{array}$ & $\begin{array}{l}\text { Mostly minds (e.g. } \\
\text { knowledge required } \\
\text { to interact, under- } \\
\text { stand, learn, etc.) }\end{array}$ \\
\hline $\begin{array}{l}\text { Resources } \\
\text { supplied by } \\
\text { service pro- } \\
\text { viders }\end{array}$ & $\begin{array}{l}\text { Products (new, re- } \\
\text { paired, refurbished, } \\
\text { etc.), spare parts, con- } \\
\text { sumables, technical } \\
\text { skills and know how, } \\
\text { methods and tools }\end{array}$ & $\begin{array}{l}\text { Mostly technical skills, } \\
\text { methods and tools }\end{array}$ & $\begin{array}{l}\text { Mostly minds (e.g. } \\
\text { knowledge required } \\
\text { to interact, analyze, } \\
\text { teach, etc.) }\end{array}$ \\
\hline
\end{tabular}

Before introducing technological innovation in a service system, its impact should be carefully assessed [16]: firstly, identifying existing/potential value expectations of customers; then, modeling the value creation process; finally, investigating how boundary can be shifted due to the adoption of technology. In section 4 we will apply these concepts to the provision of a typical field-repair intervention (i.e. recovery service).

\section{Research Methodology}

Since we needed to explore the rationales behind the scouting and the experimentation of new technologies in service systems (our unit of analysis), we adopted a multiple case study approach $[17,18]$. Purposive sampling strategy was used to be confident that the selected companies had characteristics pertinent to our aims. Finally, 6 companies carrying out pilot projects and/or introducing ICT in their service systems were selected, whose characteristics are presented in Table 2. For confidentiality reasons, their names have been disguised. Data were collected through in-depth interviews (overall, 15 respondents were interviewed) as well as recurring to secondary sources (e.g. service contracts, balance sheets, etc.). Data from interviews were coded and findings were used to model AS-IS and TO-BE delivery processes. Due to space constraints, only the case of a typical field-service for product repair is presented in the next section. 
Table 2. Characteristics of selected companies

\begin{tabular}{|c|c|c|c|c|c|c|}
\hline $\begin{array}{l}\text { Com- } \\
\text { pany }\end{array}$ & Products & $\begin{array}{l}\text { Yearly } \\
\text { revenues } \\
(M €)\end{array}$ & $\begin{array}{l}\text { Em- } \\
\text { ployees }\end{array}$ & $\begin{array}{l}\text { Served } \\
\text { area }\end{array}$ & $\begin{array}{l}\text { Installed } \\
\text { products }\end{array}$ & Informants \\
\hline $\bar{A}$ & $\begin{array}{l}\text { Production } \\
\text { printers }\end{array}$ & 83.500 & 400 & National & $\begin{array}{l}\text { Less than } \\
100\end{array}$ & $\begin{array}{l}2 \text { technicians } \\
1 \text { product specialist } \\
1 \text { service manager }\end{array}$ \\
\hline$B$ & $\begin{array}{l}\text { IT systems: } \\
\text { NAS, serv- } \\
\text { er, main- } \\
\text { frames }\end{array}$ & 3.595 .000 & 15000 & National & $\begin{array}{l}1000 \div \\
10000\end{array}$ & $\begin{array}{l}2 \text { technicians } \\
1 \text { product specialist } \\
2 \text { service managers }\end{array}$ \\
\hline C & $\begin{array}{l}\text { Liquid } \\
\text { packaging, } \\
\text { bottling } \\
\text { lines }\end{array}$ & 570.00 & 1150 & Global & $\begin{array}{l}10000 \div \\
50000\end{array}$ & 1 service manger \\
\hline$D$ & $\begin{array}{l}\text { Service of } \\
\text { gas stations }\end{array}$ & 10.200 & 60 & $\begin{array}{l}\text { Region- } \\
\text { al }\end{array}$ & $\begin{array}{l}500 \div \\
1000\end{array}$ & $\begin{array}{l}1 \text { product specialist } \\
1 \text { service manager }\end{array}$ \\
\hline E & $\begin{array}{l}\text { Turbine, } \\
\text { compres- } \\
\text { sors }\end{array}$ & 2.710 .000 & 2150 & Global & $\begin{array}{l}10000 \div \\
50000\end{array}$ & 1 service manager \\
\hline$F$ & $\begin{array}{l}\text { Trains, } \\
\text { metro, tram }\end{array}$ & 559.950 & 2150 & Global & $\begin{array}{l}500 \div \\
1000\end{array}$ & 2 service managers \\
\hline
\end{tabular}

\section{$4 \quad$ Findings and Discussion}

All the data gathered during the interviews were coded and classified in order to identify: a) the type of technology object of the scouting, b) the rationale for its introduction and c) the stage of technology introduction (Table 3). The comparison of similarities and differences among cases led to the identification of the following findings.

Finding 1. Two kinds of technology, respectively telemetry and Augmented Reality (AR), emerged as cutting edge technologies that service companies are interested in scouting and/or still introducing. Telemetry includes a set of technologies, such as sensors, SCADA and control systems, secure communication networks, databases, storage systems, etc., that are used to collect data from the field. AR, instead, relates to any technology that, superimposing virtual signs to a real scene, helps to guide its users (e.g. the field technician, the product user) in performing a task through the visualization of the right information in the right place and in real time [19]. To recognize what is viewed, retrieve, transmit and anchor the information on the user's view, software (artificial) rather than human agents can be leveraged. The first is the case of Automatic AR systems (AAR), the latter of Mobile Collaborative AR systems (MCAR) [20].

Finding 2. Since the collection of field data is central to enable the shift towards service-oriented business models, any company has (or is planning to have) telemetry to offer PRS such as condition monitoring and remote support to their products. Conversely, with respect to the adoption of $\mathrm{AR}$, most of the companies can be considered in pre-implementation stages, since they are trying to evaluate the real benefits and 
costs of its introduction through pilot projects, surveys and consultancies. The reasons for the delay in AR adoption with respect to telemetry are twofold. On one hand AR is an emerging technology that entered the market recently and that it is still in its development phase. On the other hand AR usually needs data and information to work (especially AAR) so companies that are evaluating its introduction/ introduced it, have already started/completed the introduction project of telemetry system.

Finding 3. Rationales that lead companies to scout/introduce new technologies stem from the need to reduce costs, increase productivity or create higher customer value. In the first cases, innovation is pursued to enable higher internal efficiency and to empower the workforce without sustaining remarkable costs. In the latter case, the trigger is mostly external as managers are willing to increase the value proposition of their integrated offerings.

Finding 4. Any innovation that concerns the adoption of both telemetry and AR technology strongly affects the boundaries of service systems, since it enables the provision of new services, rather than new ways of providing the same service, in the form of super- and/or self-service. Due to space limitations, in the following we will only focus on a field-service (repair from faults) and describe how the above technologies are expected to impact on the delivery process.

Table 3. Cross-case analysis

\begin{tabular}{|c|c|c|c|}
\hline $\begin{array}{l}\text { Com- } \\
\text { pany }\end{array}$ & $\begin{array}{l}\text { Technolo- } \\
\text { gy }\end{array}$ & Innovation rationales & Current stage of introduction \\
\hline$A$ & $\begin{array}{l}\text { Aug- } \\
\text { mented } \\
\text { Reality }\end{array}$ & $\begin{array}{l}\text { Improvement of diagnostic } \\
\text { skills of field technicians }\end{array}$ & $\begin{array}{l}\text { Pre-implementation assessment through a } \\
\text { pilot project }\end{array}$ \\
\hline$B$ & $\begin{array}{l}\text { Teleme- } \\
\text { try; Aug- } \\
\text { mented } \\
\text { Reality }\end{array}$ & $\begin{array}{l}\text { Guarantee the business } \\
\text { continuity 24/7; empower } \\
\text { technicians }\end{array}$ & $\begin{array}{l}\text { Implementation of online telemetry as the } \\
\text { enabler of condition monitoring services; } \\
\text { evaluation of AR technology acceptance } \\
\text { by field-force through an internal survey }\end{array}$ \\
\hline C & $\begin{array}{l}\text { Teleme- } \\
\text { try; Aug- } \\
\text { mented } \\
\text { Reality }\end{array}$ & $\begin{array}{l}\text { Analyze data and determine } \\
\text { optimal maintenance poli- } \\
\text { cies; improve communica- } \\
\text { tion between remote centers } \\
\text { and field technicians }\end{array}$ & $\begin{array}{l}\text { Implementation of telemetry (1300 ma- } \\
\text { chines monitored); condition monitoring } \\
\text { services under development; use of AR to } \\
\text { support installation }\end{array}$ \\
\hline$D$ & $\begin{array}{l}\text { Aug- } \\
\text { mented } \\
\text { Reality }\end{array}$ & $\begin{array}{l}\text { Verify the work progress } \\
\text { and support technicians in } \\
\text { troubleshooting tasks }\end{array}$ & $\begin{array}{l}\text { Use of AR to support installation/repair } \\
\text { and control progress of construction site }\end{array}$ \\
\hline$E$ & Telemetry & $\begin{array}{l}\text { Guarantee the business } \\
\text { continuity 24/7; Analyze } \\
\text { data and determine optimal } \\
\text { maintenance policies; get } \\
\text { prepared to propose upgrade } \\
\text { to the customers }\end{array}$ & $\begin{array}{l}\text { Large use of telemetry for several services } \\
\text { (e.g. maintenance and control, reporting) } \\
\text { (approx. } 1000 \text { machines monitored) }\end{array}$ \\
\hline F & $\begin{array}{l}\text { Aug- } \\
\text { mented } \\
\text { Reality }\end{array}$ & $\begin{array}{l}\text { Lower costs of field inter- } \\
\text { vention; improve communi- } \\
\text { cation between remote } \\
\text { centers and field technicians }\end{array}$ & $\begin{array}{l}\text { Pre-implementation assessment through a } \\
\text { pilot project }\end{array}$ \\
\hline
\end{tabular}


In Fig. 1, the different steps of a "repair from faults" process are presented using the PCN framework. In particular, the left side shows the AS-IS traditional process (i.e. without the adoption of telemetry and AR), while the right side shows the same process as changed by the introduction of such technologies.

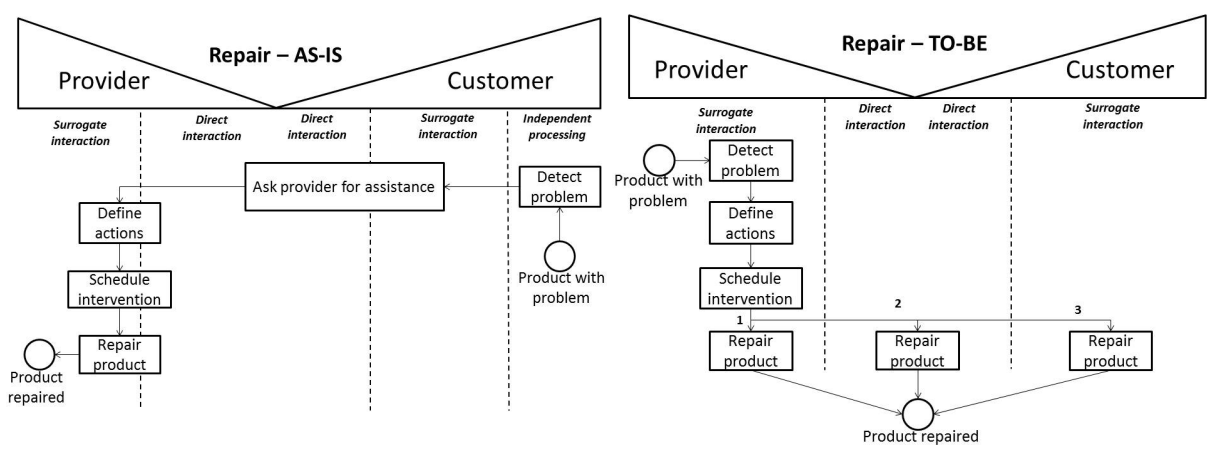

Fig. 1. PCN of field-service "repair from fault" process

In the AS-IS scenario, once problem is detected, customer initiates the service process, asking the provider for assistance. Depending on the way through which the customer contacts the provider and on the type of their interactions, this task could be performed by the customer both interacting directly with provider (direct interaction, as in the case of live chats, phone help desks, etc.) or indirectly with its resources (surrogate interaction, as in the case of sending e-mail or posting customer support requests via a web site). Since discussing the ways through which, traditionally, customers may ask for assistance, is out of the scope of the paper, we represent this task with a box that crosses direct and surrogate interactions. Once assistance is requested, the provider takes on the responsibility of the process, defines the action plan, schedules and then executes the field intervention for repairing the product. Even in this case, the level of interaction with the customer can be different; for instance, in certain cases only surrogate interactions may happen (e.g. the provider has free access to the customer facility, thus no direct interactions are required with the customer personnel) while, conversely, in other cases direct and recursive interactions are unavoidable. In this situation, super-services arise the more the adoption of telemetry spreads. In fact, through telemetry definition of action plans, scheduling and execution of interventions could be performed, to a certain extent, without direct interactions with the customer. For example, in case restoration requires only to take remote control of product (e.g. fix software bugs, optimize/administer computing power/disk allocation, release updates, etc.) the boundary of super-services can greatly be extended. For instance, this is the case of 24-hr always-on tele-control and remote maintenance services of company $\mathrm{B}$. With respect to the adoption of AR, its introduction affects more the responsibility of the "repair product" task, since this technology can assist the execution of the intervention. However, three situations emerged from 
the analysis of the cases. i) companies that are experimenting/introducing AR in their service systems state that the first application of this technology is focused on supporting their own technicians in performing technical tasks on the field. In this case (Fig.1, right side, case 1), boundary does not shift, since the provider keeps the ownership of the "repair product" task. However, the adoption of AR is expected to lead to several improvements. ii) Some companies showed interest in understanding how and when AR systems could be used to enable value co-creation (see Fig. 1, right side, case 2); MCAR, in fact, can be leveraged to establish easier/more effective communications among remote specialists (service provider's personnel) that provide assistance to product users (customer's personnel). In case customer agrees to take under its responsibility some tasks related to fixing and corrective maintenance, and execute field interventions under the supervision/support of some remote experts, the system boundary shifts towards assisted self-service by means of the introduction of AR as an enabling technology. From this situation both the provider and the customer could benefit. The first, in fact, could reduce the number of experienced technicians that are deployed on the field, and consequently the costs sustained to provide services. The second, instead, whether favored by some incentives (e.g. lower costs of service contracts, lower response time) could enable situations in which repair tasks are performed by unskilled operators, since the missing know-hows could be remotely provided by specialists. iii) A third option concerns the case in which AAR systems automatically guide customers in performing product repair, with no needs to interact with the provider anymore (see Fig. 1, right side, case 3). This is clearly a case in which the customer takes on responsibility to perform a service task previously done by the provider, thus the self-service boundary can be extended. Most of informants report that neither technology nor customers/markets seem sufficiently mature to shift towards self-repair services. Anyway, they did not deny this transition could be implemented in a nearest future, in certain circumstances, such as to replace usermanuals or to provide services in countries where no technicians reside or can be easily sent.

\section{Conclusions}

Recent advances of ICTs, and the lowering of their introduction costs, are favoring new (more efficient/effective) ways to deliver PRS. Hence, the service departments of manufacturing companies are carrying out several pilot/implementation projects to assess the benefits of adopting these technologies against the related costs. To this aim, it is essential to understand how technological innovations within service systems may enable self-services and/or super-services. This paper represents a first attempt to generate, through a multiple case-study, insights about service systems' modification and to suggest how to study the impact of ICT in service delivery. This paper has managerial implications as well, since the findings from case-studies can be useful to inform service directors, CIOs, etc., about the impacts expected by investments in new technologies. 


\section{References}

1. Atzori, L., Iera, A., Morabito, G.: The internet of things: A survey. Computer Networks 54(15), 2787-2805 (2010)

2. Allmendinger, G., Lombreglia, R.: Four Strategies for the Age of Smart Services. Harvard Business Review 83(10), 131-145 (2005)

3. Davies, A.: Moving base into high-value integrated solutions: A value stream approach. Industrial and Corporate Change 13(5), 727-756 (2004)

4. Levrat, E., Iung, B., Crespo Marquez, A.: E-maintenance: review and conceptual framework. Production Planning and Control 19(4), 408-429 (2008)

5. Davies, A., Brady, T., Hobday, M.: Charting a Path Toward Integrated Solutions. MIT Sloan Management Review 47(3), 39-48 (2006)

6. Lehtonen, O., Ala-Risku, T., Holmström, J.: Enhancing field-service delivery: the role of information. Journal of Quality in Maintenance Engineering 18(2), 125-140 (2012)

7. Voss, C.A.: Paradigms of manufacturing strategy re-visited. International Journal of Operations and Production Management 25(12), 1223-1227 (2005)

8. Campbell, C.S., Maglio, P.P., Davis, M.M.: From self-service to super-service: a resource mapping framework for co-creating value by shifting the boundary between provider and customer. Information Systems and E-Business Management 9(2), 173-191 (2011)

9. Johnson, M., Mena, C.: Supply chain management for servitised products: a multi-industry case study. International Journal of Production Economics 114(1), 27-39 (2008)

10. Roth, A.V., Menor, L.J.: Insights into service operations management: a research agenda. Production and Operations management 12(2), 145-164 (2003)

11. Maglio, P.P., Vargo, S.L., Caswell, N., Spohrer, J.: The service system is the basic abstraction of service science. Information Systems and e-business Management 7(4), 395-406 (2009)

12. de Ruyter, K., Wetzels, M., Lemmink, J., Mattsson, J.: The Dynamics of the Service Delivery Process: A Value-Based Approach. International Journal of Research in Marketing 14(3), 231-243 (1997)

13. Mathieu, V.: Product services: from a service supporting the product to a service supporting the client. Journal of Business \& Industrial Marketing 16(1), 39-61 (2001)

14. Smith, L., Ng, I., Maull, R.: The three value proposition cycles of equipment-based service. Planning \& Control: The Management of Operations 23(7), 553-570 (2012)

15. Sampson, S.E.: Visualizing Service Operations. Journal of Service Research 15(2), 182-198 (2012)

16. Lehtonen, O., Ala-Risku, T., Holmström, J.: Enhancing field-service delivery: the role of information. Journal of Quality in Maintenance Engineering 18(2), 125-140 (2012)

17. Voss, C., Tsikriktsis, N., Frohlich, M.: Case research in operations management. International Journal of Operations \& Production Management 22(2), 195-219 (2002)

18. Meredith, J.: Building operations management theory through case and field research. Journal of Operations Management 16(4), 441-454 (1998)

19. Porcelli, I., Rapaccini, M., Espindola, D.B., Pereira, C.E.: Technical and Organizational Issues about the Introduction of Augmented Reality in Maintenance and Technical Assistance Services. In: de Sales Guerra Tsuzuki, M., Silva, J.R. (eds.) 11th IFAC Workshop on Intelligent Manufacturing Systems, São Paulo, Brazil, vol. 11(1), pp. 257-262. International Federation of Automatic Control (2013), doi:10.3182/20130522-3-BR-4036.00024, ISBN: 978-3-902823-33-5

20. Billinghurst, M., Thomas, B.H.: Mobile Collaborative Augmented Reality. In: Alem, L., Huang, W. (eds.) Recent Trends of Mobile Collaborative Augmented Reality Systems, pp. 1-19. Springer, New York (2011) 